\title{
A novel grass hybrid to reduce flood generation in temperate regions
}

\section{SUBJECT AREAS:}

HYDROLOGY

PLANT PHYSIOLOGY

ECOSYSTEM SERVICES

GRASSLAND ECOLOGY

Received

23 November 2012

Accepted

4 April 2013

Published

25 April 2013

Correspondence and requests for materials should be addressed to

C.J.A.M. (kit. macleod@hutton.ac.
Christopher (Kit) J. A. Macleod' ${ }^{1,2}$, Mike W. Humphreys ${ }^{3}$, W. Richard Whalley ${ }^{4}$, Lesley Turner ${ }^{3}$, Andrew Binley ${ }^{5}$, Chris W. Watts ${ }^{4}$, Leif Skøt ${ }^{3}$, Adrian Joynes', Sarah Hawkins ${ }^{3}$, lan P. King ${ }^{3,6}$, Sally O'Donovan ${ }^{3} \&$ Phil M. Haygarth ${ }^{5}$

${ }^{1}$ Rothamsted Research, North Wyke, Devon, EX20 2SB, UK, ${ }^{2}$ The James Hutton Institute, Aberdeen, AB15 8QH, UK, ${ }^{3}$ Institute of Biological, Environmental and Rural Sciences (IBERS), Aberystwyth University, Aberystwyth, Wales, SY23 3EB, UK, ${ }^{4}$ Rothamsted Research, Harpenden, Herffordshire, AL52JQ, UK, ${ }^{5}$ Lancaster Environment Centre, Lancaster University, Lancaster, UK, LA1 4YQ, UK, ${ }^{6}$ School of Biosciences, University of Nottingham, LE 12 5RD, UK.

We report on the evaluation of a novel grass hybrid that provides efficient forage production and could help mitigate flooding. Perennial ryegrass (Lolium perenne) is the grass species of choice for most farmers, but lacks resilience against extremes of climate. We hybridised $L$. perenne onto a closely related and more stress-resistant grass species, meadow fescue Festuca pratensis. We demonstrate that the L. perenne $\times$ F. pratensis cultivar can reduce runoff during the events by $51 \%$ compared to a leading UK nationally recommended $L$. perenne cultivar and by $43 \%$ compared to $F$. pratensis over a two year field experiment. We present evidence that the reduced runoff from this Festulolium cultivar was due to intense initial root growth followed by rapid senescence, especially at depth. Hybrid grasses of this type show potential for reducing the likelihood of flooding, whilst providing food production under conditions of changing climate.

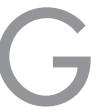

lobal precipitation patterns are changing with drought in some areas and rainfall, including rainfall intensity, increasing in others ${ }^{1}$, especially in the northern hemisphere ${ }^{2}$. Increased rainfall intensity causes greater runoff and streamflow ${ }^{3}$ and potential for increased likelihood of flooding ${ }^{4}$. Winter stream flow in particular is increasing in central, northern and western Europe $e^{5}$. Understanding the role of agricultural land management in flood prevention is a key challenge ${ }^{6,7}$. Grasslands cover $69 \%$ of global agricultural land ${ }^{8}$ and therefore offer great potential to intercept rainfall or modify runoff generation and potentially mitigate flood risk ${ }^{9}$.

Hybrid formation and consequent persistence and fecundity are important contributors to plant speciation and evolution. They are often necessary for the successful colonisation of environments previously beyond the range of adaptation of their parent genotypes. The grasses that comprise the Festuca genus are excellent examples where hybridisation has provided enhanced adaptations to climatic and edaphic (soil environment) extremes ${ }^{10}$. Several Festuca (fescue) species hybridise readily with the major agricultural forage grasses of the Lolium (ryegrass) genus, providing plant breeders with opportunities to combine their complementary traits ${ }^{11}$. In particular, there is potential to integrate the rapid establishment, growth rate and forage quality of Lolium with the large well developed root systems and efficient water and nutrient capture of Festuca species ${ }^{11}$. As intergeneric hybrids, cultivars classified as Festulolium are being developed ${ }^{11}$ that may have the required developmental and phenotype plasticity necessary to combat climatic extremes such as flooding or drought. The choice of the appropriate Lolium $\mathrm{x}$ Festuca species combination will depend on where the crop will be grown and the climatic and edaphic stresses anticipated.

\section{Results}

Reduced plot scale runoff generation from a Festulolium hybrid. As part of a long-term breeding programme to understand the genetic basis of trait variation in grasses, we have developed Festulolium loliaceum cv Prior (hereafter Prior). Here, we show that Prior had a significant impact on rainfall runoff compared to either parental species. Over a two-year period, Prior reduced event runoff by $51 \%$ compared to the UK National Listed perennial ryegrass cultivar L. perenne cv AberStar, and by $43 \%$ compared to a meadow fescue cultivar Festuca pratensis Huds. cv. Bf 993 , a progenitor of cultivar S215, the fescue parent of Prior (over two years, replicated randomized-block design) (Figure 1). Of the six grass cultivars tested, comprising two Festulolium hybrids (the other being a Lolium multiflorum x Festuca arundinacea var glaucescens cultivar, hereafter 99/1) and their respective parental species, Prior had consistently the least runoff in 29 out of 33 individual rainfall runoff events whereas 

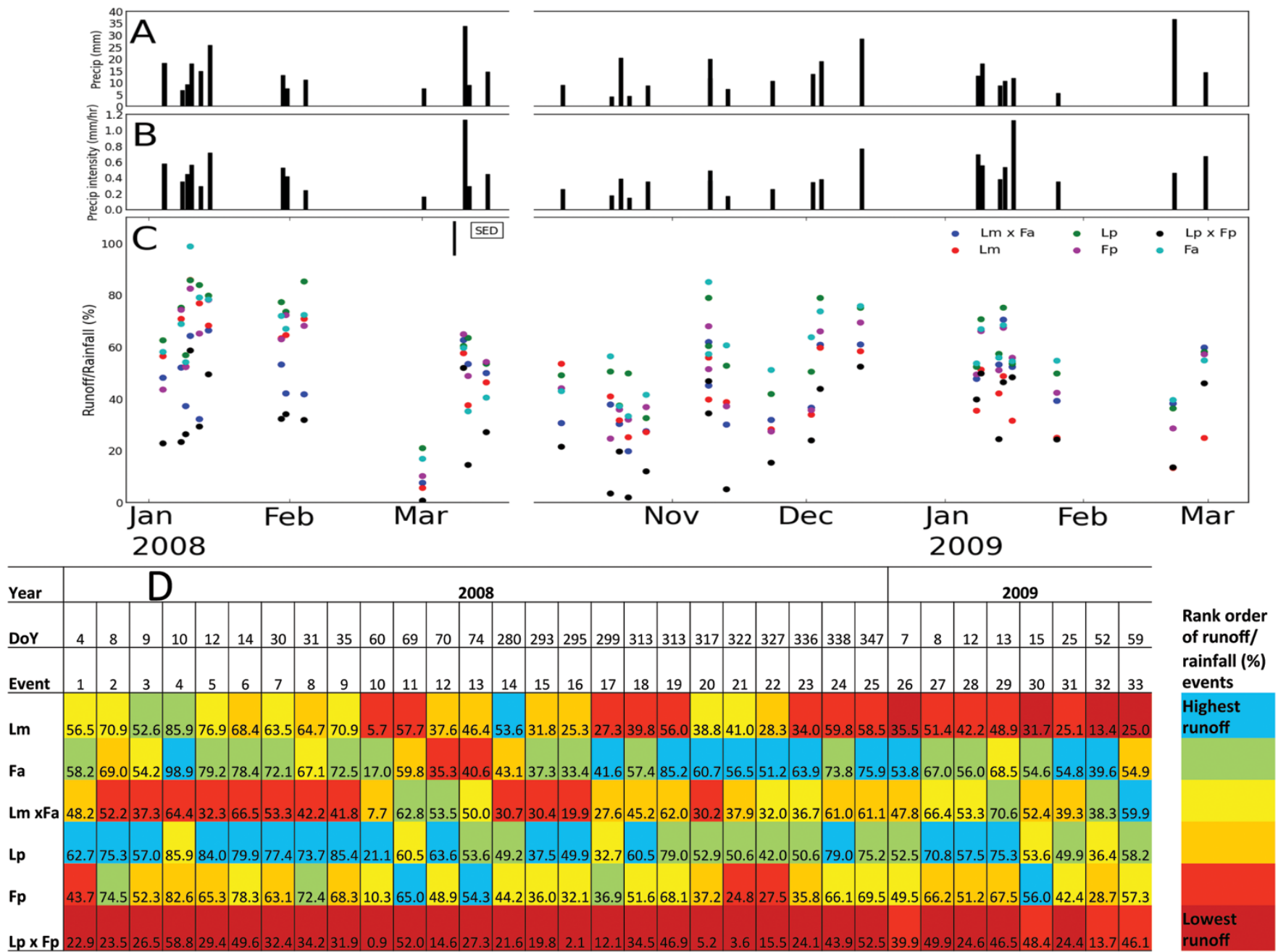

Figure 1 Time series of total precipitation, precipitation intensity and reduced plot scale runoff in Festulolium hybrid over a two year period. Box A total precipitation $(\mathrm{n}=2)$ time series for runoff events. Box B precipitation intensity $(\mathrm{mm} / \mathrm{hr})$ time series for runoff events. Boxes $\mathrm{C}$ and $\mathrm{D}$ mean plot scale runoff/rainfall $(\%)$ ((runoff (surface and 0-30 cm) for the event duration divided by the rainfall for the event duration)*100) $(\mathrm{n}=3)$ from six grasses (Lp-Lolium perenne cv AberStar, Fp-Festuca pratensis cv Bf993, LpxFp- L. perenne x F. pratensis cv Prior, Lm-Lolium multiflorum,cv AberEpic, Fa-Festuca arundinacea cv Dovey, and LmxFa-L. multiflorum $\mathrm{x}$ F. arundinacea var glaucescens $\mathrm{cv}$ 99/1). Statistical analysis of the runoff coefficients with variable time steps used a power function-the simplest correlation structure, where the power index is the absolute time in days between the assessments. Restricted maximum likelihood (REML) was used to determine if such a model was required. The models were compared using the difference between the residual deviances $(-2 * \log$ likelihood). The difference in deviances is 84 on 1 degree of freedom (this is a chi-square statistic and is highly statistically significant). Standard error of differences of means (SED) is presented. Runoff measurements were made using high resolution (one min) data collection from laboratory and field calibrated tipping buckets from March 2007. Analysis of the time series datasets identified 33 individual rainfall events.

L. perenne cv AberStar had the highest incidence of runoff in 17 rainfall runoff events. The Festulolium hybrid 99/1 initially had the second lowest runoff (after Prior), but following the 2008 growing season 99/1 was less effective at reducing runoff compared to its ryegrass parent (Figure 1). This is the first report that supports a clear multifunctional role for Festulolium as a sustainable agricultural crop bred to endure abiotic stresses ${ }^{12}$ that also provides a regulatory ecosystem service ${ }^{13}$ of major economic importance in temperate regions by significantly reducing runoff and the likelihood of flooding.

Rainfall accumulations (\% of 1961-90 average) and return period estimates for the South West of England for 2008 and 2009 were $110 \%$ and $2-5$ years, indicating average rainfall amounts. The flow in the River Taw (which the Rowden plots drain into) was $109 \%$ in 2008 and $97 \%$ in 2009 and were classed as normal flows ${ }^{14}$. In 2008 and 2009 , rainfall during the winter months (October to March) provided $56 \%$ of the annual precipitation compared to $63 \%$ for the $1961-2000$ long term average. For the duration of the rainfall-runoff events, rainfall for the winter months from January 2008 to March 2009 was $825 \mathrm{~mm}$ compared to $973 \mathrm{~mm}$ for the 1961-2000 long term average.

We did not measure transpiration directly in the North Wyke rainfall-runoff plot experiment. This study presents rainfall-runoff events from the months of October to March, which for 2008 had lower levels of average FAO Penman-Monteith calculated daily potential evapotranspiration (ET) of $0.6 \mathrm{~mm} \mathrm{~d}^{-1}$ (0.3 s.d.), compared to the daily average for the months April to September of $1.4 \mathrm{~mm} \mathrm{~d}^{-1}$ (0.5 s.d.).

Root growth and turn-over. We tested whether these favourable effects on runoff were caused by differences in root growth and turn-over ${ }^{15}$. We conducted root development studies on the two Festulolium hybrids and their respective parental species over a two year growing period. We found in all cases that, subsequent to an initial six month establishment phase during which major root development occurred, there followed a phase of significant root senescence $(\mathrm{P}<0.001)$ (Figure 2$)$. Only in the F. pratensis cultivar 

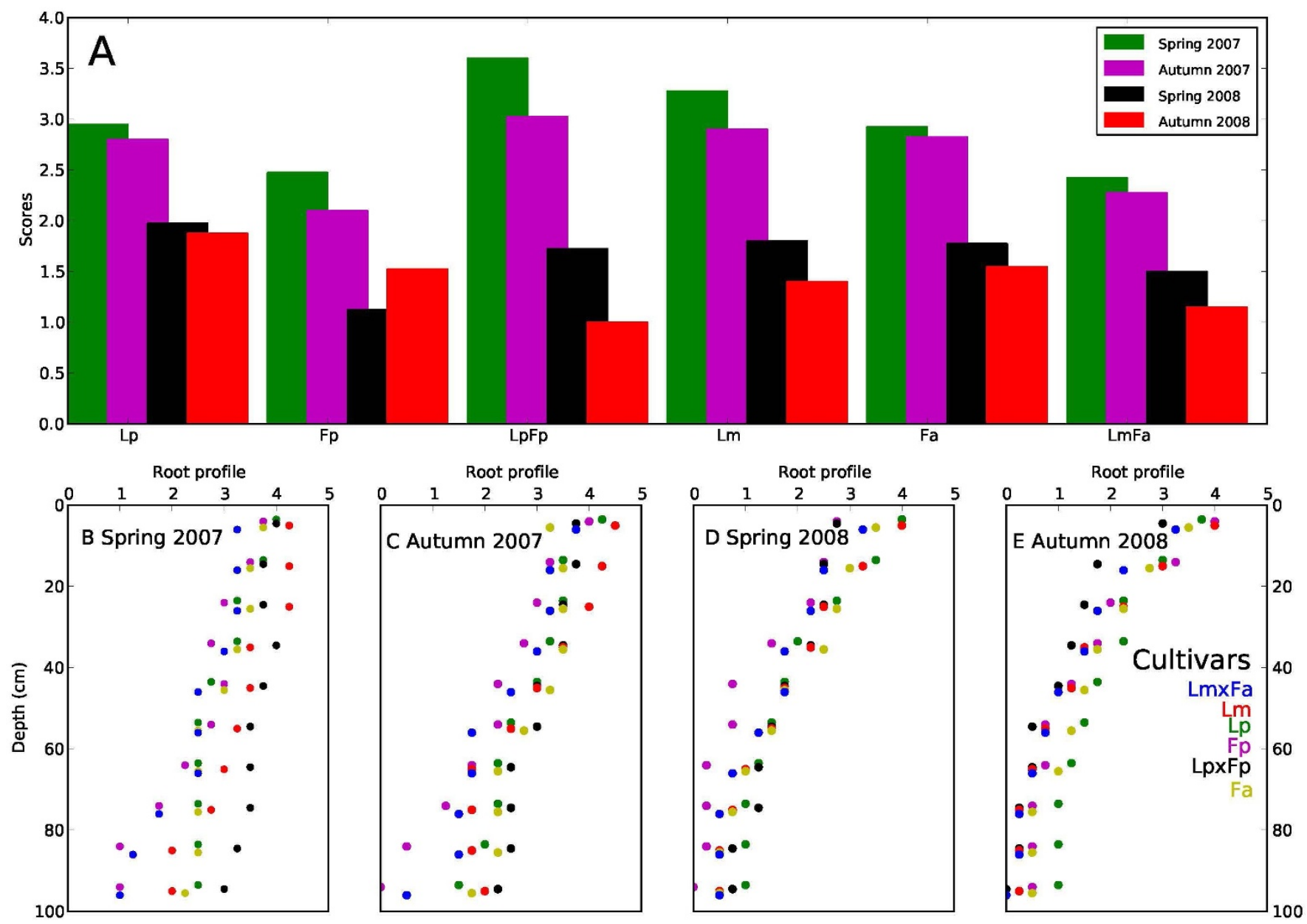

Figure $2 \mid$ Changes over two consecutive years to root system size in Lolium and Festuca species and their hybrids. Box A shows significant degeneration $(\mathrm{P}<0.001)$ in overall root system size following an initial 6 months establishment of forage grass cultivars Lolium perenne cv AberStar $(L p)$, Festuca pratensis cv Bf993 (Fp), L. perenne x F. pratensis cv Prior (LpxFp), Lolium multiflorum cv AberEpic (Lm), Festuca arundinacea cv Dovey (Fa), and L. multiflorum $\mathrm{x}$ F. arundinacea var glaucescens $\mathrm{cv} 99 / 1(\mathrm{LmxFa})$ throughout one meter soil columns $(\mathrm{n}=4)$ observed on April 16 th and September 17 th over two growing seasons. Boxes B-E "dissect" these root systems (shown in A) into consecutive 10-cm fractions distributed along the one meter soil columns to show significant $(\mathrm{P}<0.001)$ root growth and senescence ( timepoints ${ }^{25}$.

Bf993 was there evidence for root system recovery during the second summer. A significant difference between cultivars was found in both overall root size and distribution through a one meter soil column $(\mathrm{P}<0.001)$. In April, six months after establishment, Prior had produced both the largest and most extensively distributed root system throughout the one meter soil cores. However, after two years' growth, Prior retained the lowest number of roots throughout the soil core amongst all six cultivars, with new root growth confined to near the soil surface (Figure 2). In the field hydrological study, equivalent root growth and senescence was also observed in Prior using soil core samples and root measurements ${ }^{16}$. The Festulolium cultivar 99/1 had, in contrast to Prior, a comparatively small root system, which was smaller in size to either its parental species and was less able to limit rainfall runoff. One of the 99/1 parental species L. multiflorum had a similar pattern of root turn-over to Prior (Figure 2), but its overall root size and the consequent effect on soil hydrology was inferior in 2008 (Figure 1).

Herbage growth characteristics. The Festulolium cultivar Prior was found to have similar above ground growth characteristics in terms of biomass yield as its parental species L. perenne cv AberStar (Table 1). Whereas the Festulolium cultivar 99/1 was found to have significantly $(\mathrm{P}=0.05)$ lower biomass yields at all time points compared to its parental species L. multiflorum cv AberEpic. L. multiflorum cv AberEpic was only second to Festuca arundinacea $\mathrm{cv}$ Dovey in terms of above ground biomass produced over the duration of the experiment (Table 1). This data shows that the Festulolium hybrid Prior was not the tallest grass or had the greatest biomass. There is in general, a positive relationship between grass height (and leaf area index; which we did not measure) and rate of $\mathrm{ET}^{17}$. In a related microcosm experiment (unpublished data) we measured predawn leaf water potential and found no significant differences between the grass cultivars.

Soil matric potential. Automated tensiometers were used to monitor how the soil water status was changing within the experimental plots between the six grass cultivars over time. Changes in matric potential at 20 and $60 \mathrm{~cm}$ during 2008 from the two sets of runoff end members (pairs of cultivars with the lowest and highest average rainfall runoff percentages over 2008 events) are presented in Figure 3. This data indicates that the rapid growth and turnover of roots in the Festulolium hybrids resulted in greater soil water storage capacity in the plots with observed lower rainfall runoff.

Electrical resistivity tomography. We used Electrical resistivity tomography (ERT) to monitor spatial patterns of soil moisture ${ }^{18,19}$ 
Table 1 | Plot grass growth characteristics (2007-2009). Dry matter biomass (for first cut and total for five cuts) and sward height (first cut only) is presented for six grasses (Lp-Lolium perenne cv AberStar, Fp-Festuca pratensis cv BF993, LpxFp-L. perenne x F. pratensis cv Prior, Lm-Lolium multiflorum, cv AberEpic, Fa-Festuca arundinacea cv Dovey, and LmxFa-L. multiflorum x F. arundinacea var glaucescens $\mathrm{cv}$ $99 / 11$

\begin{tabular}{|c|c|c|c|c|c|c|c|c|c|}
\hline & \multicolumn{3}{|c|}{2007} & \multicolumn{3}{|c|}{2008} & \multicolumn{3}{|c|}{2009} \\
\hline & \multicolumn{2}{|c|}{ First cut ${ }^{a}$} & \multirow{2}{*}{$\begin{array}{c}\text { All five cuts } \\
\text { Biomass } \\
\text { (kg DM/ha) }\end{array}$} & \multicolumn{2}{|c|}{ First cut } & \multirow{2}{*}{$\begin{array}{c}\text { All five cuts } \\
\text { Biomass } \\
(\mathrm{kg} \mathrm{DM} / \mathrm{ha})\end{array}$} & \multicolumn{2}{|c|}{ First cut } & \multirow{2}{*}{$\begin{array}{c}\text { All five cuts } \\
\begin{array}{c}\text { Biomass } \\
(\mathrm{kg} \mathrm{DM} / \mathrm{ha})\end{array}\end{array}$} \\
\hline & $\begin{array}{l}\text { Height } \\
(\mathrm{cm})\end{array}$ & $\begin{array}{c}\text { Biomass } \\
(\mathrm{kg} \mathrm{DM} / \mathrm{ha})\end{array}$ & & $\begin{array}{l}\text { Height } \\
(\mathrm{cm})\end{array}$ & $\begin{array}{l}\text { Biomass } \\
\text { (kg DM/ha) }\end{array}$ & & $\begin{array}{l}\text { Height } \\
(\mathrm{cm})\end{array}$ & $\begin{array}{c}\text { Biomass } \\
(\mathrm{kg} \mathrm{DM} / \mathrm{ha})\end{array}$ & \\
\hline $\begin{array}{l}\text { Lp-Lolium perenne cv } \\
\text { AberStar }\end{array}$ & 26.5 & 1912 & 8117 & 18.2 & 2810 & 8946 & 22.2 & 1480 & 11827 \\
\hline $\begin{array}{l}\text { Fp-Festuca pratensis } \\
\text { cv Bf993 }\end{array}$ & 30.7 & 2202 & 8392 & 21.5 & 3296 & 10214 & 20.1 & 1288 & 10156 \\
\hline $\begin{array}{l}\text { LpxFp- L. perenne x } F \text {. } \\
\text { pratensis cv Prior }\end{array}$ & 30.5 & 2040 & 8518 & 23.8 & 3054 & 9170 & 24.0 & 1759 & 11468 \\
\hline $\begin{array}{l}\text { Lm-Lolium multiflorum } \\
\text { cv AberEpic }\end{array}$ & 46.9 & 2901 & 10272 & 35.1 & 3427 & 10980 & 37.0 & 2698 & 13284 \\
\hline $\begin{array}{l}\text { Fa-Festuca } \\
\text { arundinacea cv Dovey }\end{array}$ & 42.3 & 3316 & 11301 & 31.3 & 3593 & 12126 & 36.5 & 2241 & 12851 \\
\hline $\begin{array}{l}\text { LmxFa-L. multiflorum } \\
x \text { F. arundinacea var } \\
\text { glaucescens cv } 99 / 1\end{array}$ & 31.6 & 2072 & 7906 & 25.6 & 2884 & 9114 & 25.3 & 1449 & 11008 \\
\hline $\begin{array}{l}\text { F pr } \\
\text { LSD }(5 \%)\end{array}$ & $\begin{array}{r}<0.001 \\
3.55\end{array}$ & $\begin{array}{c}<0.001 \\
460\end{array}$ & $\begin{array}{r}<0.001 \\
993\end{array}$ & $\begin{array}{r}<0.001 \\
3.63\end{array}$ & $\begin{array}{r}0.036 \\
509\end{array}$ & $\begin{array}{r}<0.001 \\
709\end{array}$ & $\begin{array}{r}<0.001 \\
2.77\end{array}$ & $\begin{array}{c}<0.001 \\
477\end{array}$ & $\begin{array}{r}0.001 \\
1177\end{array}$ \\
\hline
\end{tabular}

to non-invasively obtain $2 \mathrm{D}$ maps of the variation in soil electrical resistivity. This allowed us to infer changes in soil moisture ${ }^{18,19}$ due to the activity of the different grasses (Figure 3 ). We found significantly $(\mathrm{P}<0.01)$ higher resistivity in Prior compared to L. perenne $\mathrm{cv}$
AberStar and F. pratensis cv Bf993 at two separate time points that spanned the rainfall runoff results (Figure 4). ERT data showed that the soil in the root-zone of Prior had a much higher electrical resistivity than the other grasses on both occasions (Figure 4). This
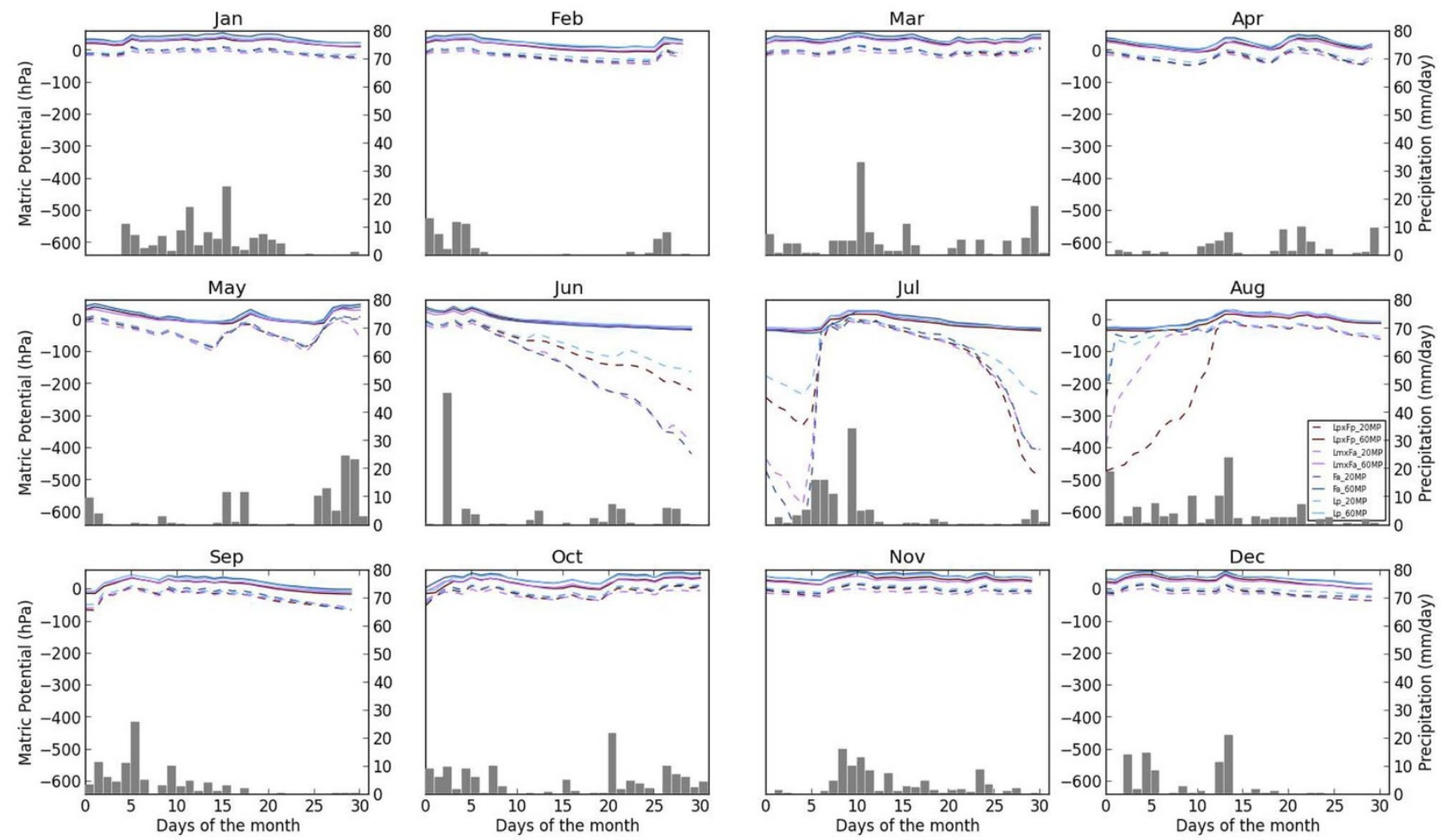

Figure 3 Changes in soil matric potential during 2008 indicating greater soil water storage capacity in the Festulolium plots. The lower soil matric potentials at 20 and $60 \mathrm{~cm}$ in the LpxFp-L. perenne $x$ F. pratensis $\mathrm{cv}$ Prior and LmxFa-L. multiflorum $\mathrm{x}$ F. arundinacea var glaucescens cv 99/1 Festulolium hybrids (which had the lowest average rainfall runoff percentages for the 2008 events) compared to Lolium perennecv AberStar and Festuca arundinacea cv Dovey (which had the highest average rainfall runoff percentages for the 2008 events). 
is due to the rapid growth and senescence of Prior's roots, resulting in greater storage in the soil profile and lower water content of the surface soil layers.

Tension-infiltration. We carried out field based tension infiltration measurements on four occasions (May 2007, October 2007, May 2008 and July 2008), where the flux of water into the soil was measured at a range of negative pressures $(-2,-1.5,-1.0,-0.5$ and $0 \mathrm{kPa})^{20}$. This technique measures the hydraulic properties of the surface soil. We found that the greatest infiltration rate was in Lolium perenne cv AberStar, followed by Festuca arundinacea cv Dovey, L. multiflorum x F. arundinacea var glaucescens $\mathrm{cv}$ 99/1, L. perenne $x$ F. pratensis cv Prior and Lolium multiflorum,cv AberEpic.

\section{Discussion}

Poor infiltration of water into soil is sometimes explained in terms of biologically induced water repellence ${ }^{21}$, but we found no difference $(\mathrm{P}=0.117)$ in the wettability (as measured with the capillary rise method $^{22}$ ) for soils in the different grass plots ${ }^{20}$. We conclude that the differences in infiltration (Figure 1) and soil water content of the profile (Figures 3 and 4 ) are due to differences in the spatial organization of soil, commonly referred to as soil structure. There are two likely mechanisms responsible for changes to soil structure. First, the soil used in the experiments is known to shrink on drying and, in a parallel laboratory experiment, we observed cultivar differences in drying rates likely to cause soil shrinkage and therefore induced soil structure. Second, we suggest that the senescing roots that penetrated the deeper soil layers are likely to leave bio-pores that can transmit water to depth, resulting in a greater soil water storage capacity. The tensiometer data (Figure 3 ) indicates that for long periods of time the water table was near the surface, resulting in the high rainfall runoff percentages. This data also indicates that there is a decrease in the water table in the plots between events.

The rapid root development and senescence (Figure 2) in the Prior cultivar is likely to be an important control on runoff generation and therefore the likelihood of flooding. The longevity of these effects on runoff generation is unknown. Though, vertical cylindrical pores (like those created by grass roots) have been shown to be more stable compared to interaggregate pores ${ }^{23}$. Further research is required to assess when and to what degree improvements in plot to landscape scale soil water storage capacity can contribute to reducing runoff generation and mitigating the risk of flooding.

The resilience of the Festulolium cultivar Prior against climatic and edaphic stresses found commonly throughout temperate regions of the world, makes possible its widespread use as both a support to sustainable agricultural practice and a safeguard against flooding.

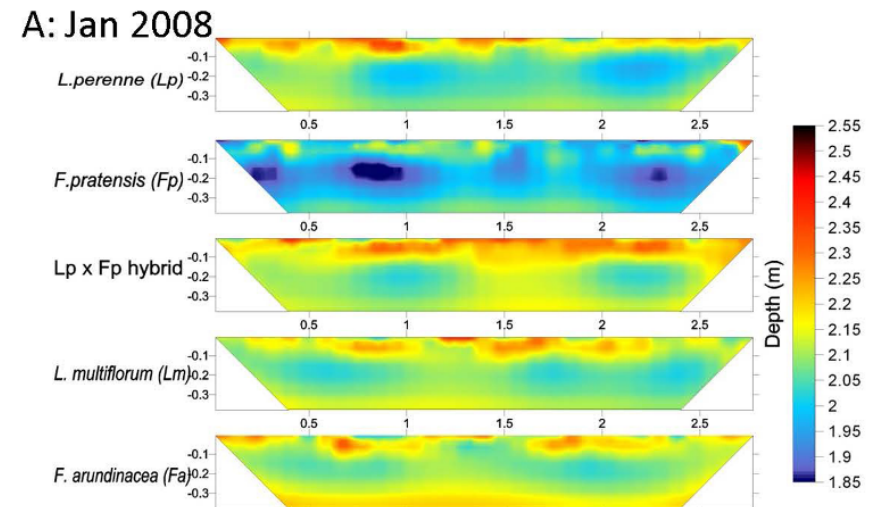

\begin{tabular}{lcc}
\hline Cultivar & $\mathbf{0 - 2 0} \mathbf{~ c m}$ & $\mathbf{0 - 4 0 ~} \mathbf{c m}$ \\
\hline L. perenne & 135.2 & 133 \\
F. pratensis & 100.8 & 101.7
\end{tabular}

Prior hybrid $\quad 152.2 \quad 148.2$

L. Multiforum $135.1 \quad 134.2$

F. Arundinacea $\quad 134.1 \quad 137.6$

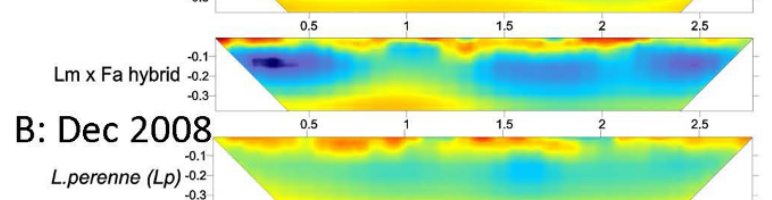
Resistivity (lo

99/1 hybrid

135.6

139.1

\begin{tabular}{lll}
\hline sed & 1.4 & 0.9
\end{tabular}
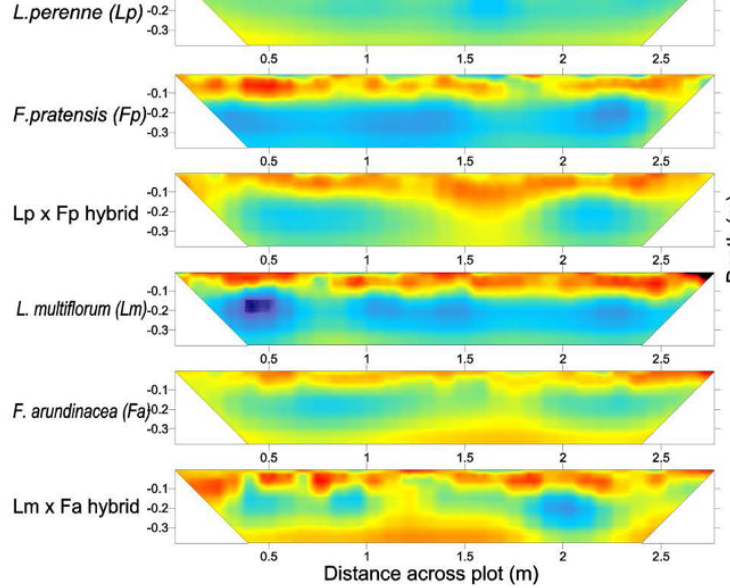

\begin{tabular}{|c|c|c|c|}
\hline 2.55 & Cultivar & $0-20 \mathrm{~cm}$ & $0-40 \mathrm{~cm}$ \\
\hline $\begin{array}{l}2.45 \\
2.4 \\
2.35\end{array}$ & L. perenne & 135.4 & 134.5 \\
\hline $\begin{array}{l}-2.3 \\
2.25\end{array}$ & F. pratensis & 139.8 & 131.8 \\
\hline $\begin{array}{l}2.15 \\
-2.1 \\
2.15\end{array}$ & Prior hybrid & 152.7 & 146.2 \\
\hline $\begin{array}{l}2.05 \\
-2 \\
-1.95\end{array}$ & L. Multiforum & 150.3 & 140.2 \\
\hline $\mathbf{L}_{1.85}^{1.9}$ & F. Arundinacea & 141.2 & 142.2 \\
\hline Resistivity (log) & $99 / 1$ hybrid & 152.1 & 152.8 \\
\hline & sed & 1.8 & 1.1 \\
\hline
\end{tabular}

Figure $4 \mid$ Differences in plot scale 2D electrical resistivities indicating Festulolium induced soil surface drying. Higher surface resistivities in Prior treatment compared to other grass cultivars indicates lower water content in January 2008 (A) and December 2008 (B). Data are 2D electrical resistivities, $\log 10$ (resistivity in Ohm-m). from electrical resistivity tomography, determined using a 32-electrode 2.9 meter length Wenner array with 0.09 meter minimal electrode spacing. The computed electrical resistivity measures the ability of the soil to restrict flow of electrical current laterally and vertically. The six treatments were Lp-Lolium perenne cv AberStar, Fp-Festuca pratensis cv Bf993, LpxFp- L. perenne x F. pratensis cv Prior, Lm-Lolium multiflorum,cv AberEpic, Fa-Festuca arundinacea cv Dovey and LmxFa-L. multiflorum x F. arundinacea var glaucescens $\mathrm{cv} 99 / 1$. Average values over 0-20 and 0-40 cm depths across 2D transects. Statistics carried out using a two-way ANOVA with Genstat $13^{\text {th }}$ edition. 
This is a timely finding during a period of increasing rainfall intensity ${ }^{1,2}$ and flooding ${ }^{4}$.

\section{Methods}

Experimental design and plant material. Three replicate $10 \times 3 \mathrm{~m}$ plots of Lolium perenne cv AberStar (Lp) (diploid), Festuca pratensis cv Bf993 (Fp) (diploid), L. perenne $\times$ F. pratensis cv Prior (LpxFp) (tetraploid), Lolium multiflorum cv AberEpic (Lm) (diploid), Festuca arundinacea cv Dovey (Fa) (hexaploid), and L. multiflorum $\mathrm{x}$ F. arundinacea var glaucescens $\mathrm{cv} 99 / 1$ ( $\mathrm{LmxFa}$ ) (tetraploid) were established on a planar hillslope $\left(5^{\circ}\right)$ on a clay rich soil (Typic Haplaquept (USDA classification) or Dystric Gleysol (FAO classification)), and subsequently maintained over three entire growing seasons (2006-2009) at Rothamsted's North Wyke Research, Devon, UK. The Rowden research platform of which these plots were part of is situated on the Hallsworth soil series. This soil series represents the most common hydrologic soil type in England and Wales, covering approximately 13.9\% of the land area according to the Hydrology of Soil Types classification system ${ }^{24}$. The study site was carefully chosen to have a homogenous soil texture so as to remove the potential for soil texture to influence the soil water balance.

The rainfall runoff plots were drilled in an identical manner using a professional small plot drill (Hege seed drill) operated by an experienced member of staff. The plots were drilled along their length (10 meter) with a buffer ( 2 meter) on the upper and lower boundaries to ensure no mixing of different grass seeds. At the start of each plot and buffer area the correct mass of seeds was added to the drill and seeds planted. The spacing of the rows was $11.5 \mathrm{~cm}$. The sowing rate accords with commercial field trials throughout Europe: $2.2 \mathrm{~g} \mathrm{~m}^{2}$ for diploids (Lolium perenne cv AberStar, Lolium multiflorum,cv AberEpic and Festuca pratensis cv Bf993) and $3.3 \mathrm{~g} \mathrm{~m}^{2}$ for the tetraploids and hexaploids (L. perenne $x$ F. pratensis cv Prior, L. multiflorum $\mathrm{x} F$. arundinacea var glaucescens cv 99/1 and Festuca arundinacea cv Dovey). The seeds of diploid grasses are smaller, so require a smaller mass of seed to produce an equivalent ground cover. Visual checks were made after six months of growth to ensure plots had been drilled with the correct grass material. A homogenous sward was maintained by manual weeding from June 2006 until the end of 2009.

The plots were fertilized at the start of the growing season and following five herbage cuts for which dry matter yield was determined gravimetrically (middle of April, then at the start of June, July and August and then in the middle of September). In total approximately $250 \mathrm{~kg} / \mathrm{ha}$ of mineral $\mathrm{N}$ fertilizer was added with $90 \mathrm{~kg} / \mathrm{ha} \mathrm{P}$ and $120 \mathrm{~kg} / \mathrm{ha}$ of $\mathrm{K}$ per annum in line with guidelines at the time and soil testing for $\mathrm{P}$ and K. Soil cores were taken from the field plots in the Autumn of 2007 and 2008 and root mass determined gravimetrically after washing ${ }^{16}$.

During an identical period (summer 2006), five equal sized clones comprising five representative genotypes of the six cultivars were established and maintained in heated ( $\min$ temp $8^{\circ} \mathrm{C}$ ) glasshouse conditions in freely draining polythene-lined one meter deep pipes filled with John Innes No3 Potting Compost $(n=4)^{25}$. Above ground growth was determined at the same time points in 2007 and 2008 as the field experiment. Plants were cut back to five $\mathrm{cm}$ and dry matter determined gravimetrically. Root growth measurements were made by non-destructive scoring of visible roots in $10 \mathrm{~cm}$ sections viewed through the one meter polythene sleeve extracted from the glasshouse pipes at IBERS in April and September 2007 and 2008 concurrent with foliage harvest ${ }^{25}$. The maximum depth at which roots were visible was recorded and root density for each $10 \mathrm{~cm}$ section was scored on a scale of 0 (no roots visible) to 4 (extremely dense rooting). The proportion of roots that were white or very pale colour were classed as "new roots" 26 . Other roots were classed as "old roots". Root system size was the sum of scores for all these sections and root profile was the regression coefficient for a line fitted through the root from the lowest section to the surface.

Plot herbage production. Plot herbage dry matter yield and sward height was determined at five time points each year in 2007-2009 (during weeks 16, 23, 29, 33 and 38). Sward height was measured by taking 10 measurements at one meter intervals along the length of each plot. Herbage yield was determined by measuring the mass of an eight meter strip of each plot using a Haldrop small plot harvester. Subsamples were taken from each plot and the moisture content was determined gravimetrically through drying (at $100^{\circ} \mathrm{C}$ ) to a constant mass. The grass cultivars in the IBERS microcosm were harvested during the same weeks.

Plot rainfall runoff. Rainfall was measured using two Delta T RG1 rainfall gauges (standard meteorological equipment) within the plots. The plots were hydrologically isolated from lateral flows through gravel drainage ditches top and bottom and plastic sheeting inserted to $40 \mathrm{~cm}$ depth (10 $\mathrm{cm}$ above soil surface) along the plot sides. Visual inspections were made at regularly intervals to ensure that water was not flowing onto or off the plots through the side surface barriers. Runoff was collected along two hydrological pathways: the upper capturing water moving across the vegetated soil surface and to a depth of five $\mathrm{cm}$ (through careful insertion of plastic sheeting $10 \mathrm{~cm}$ into the plot that fed plastic guttering); and a lower pathway to a depth of $30 \mathrm{~cm}$ in the clay $\mathrm{Bg}$ horizon. The $\mathrm{Bg}$ soil horizon is a clay and has a low saturated hydraulic conductivity $\left(<10^{-10} \mathrm{~ms}^{-1}\right)^{27}$. The assumption is that vertical losses and gains of water through the subsurface will be low, especially when the soil is saturated and over short durations (the events reported in this paper). A number of hydrological studies on the Rowden experimental platform have found these to be the main hydrological pathways during saturated conditions, with some loss to the groundwater ${ }^{28}$. This later pathway fed to a plastic lined trench that was backfilled with $40 \mathrm{~mm}$ gravel drainage and a slotted drainage pipe. Water in these two hydrological pathways was measured using calibrated (laboratory and field) tipping buckets ${ }^{29}$ both recording at one minute intervals. In this paper the combined runoff from these two hydrological pathways is presented as ((runoff for the event duration divided by the rainfall for the event duration)*100).

Soil matric potential. In 2007, UMS T4 (without external refilling) pressure transducer tensiometers were inserted to 20 and $60 \mathrm{~cm}$ in one block of the grass cultivar treatments. Readings of matric potential were automatically recorded at one minute intervals and regularly downloaded from Delta T GP1 data loggers. The T4 tensiometers were chosen since they can provide reliable outdoor measurements of soil water tension from $+100 \mathrm{kPa}$ to $-85 \mathrm{kPa}$. The tensiometers were installed according to manufactures guidance ${ }^{30}$. At the end of September in 2007 and 2008 the tensiometers were removed to check for the presence of air bubbles and to recalibrate, before the start of the winter drainage season.

Electrical resistivity tomography (ERT). We collected 2D electrical resistivities using D.C. resistivity metering applied with a 32 electrode Wenner array on a fixed support ( $0.09 \mathrm{~m}$ spacing and $2.9 \mathrm{~m}$ length). D.C. resistivity metering measures the ability of the soil to restrict the flow of electrical current laterally and vertically. A GEOPULSE resistance meter and multiplexor switching unit enabled computer controlled automatic survey collection over two cycles of repeated measurements. Good contact between the electrodes (three $\mathrm{cm}$ ) and soil was tested for using the GEOPULSE resistance meter. Spatial variation in resistivity was determined using four-electrode measurements. Two electrodes were used to establish an electrical circuit with measurement of the potential difference between two additional electrodes enables determination of apparent resistivity ${ }^{31}$. The aim of resistivity measurements was to derive the distribution of electrical properties of the subsurface from a set of measurements taken from the soil surface. Given the surface apparent resistivities (data) then an "inverse problem" was solved to produce a distribution of electrical properties (model) to explain the data. The inverse problem was solved as a regularized optimization problem involving the minimising of an objective function and a penalty term of deviation from desired model attributes ${ }^{31}$. The average $(n=2)$ resistivities underwent an inversion using a quadrilateral finite element mesh with the Profiler inversion software ${ }^{31,32}$. Soil electrical resistivities are dependent on temperature; the output resistivities were adjusted ${ }^{33}$ using soil temperature data collected at the time of resistivity surveys using in-situ thermistor temperature probes at 10,20, and $40 \mathrm{~cm}$ depths (ST2, Delta T).

1. Groisman, P. Y.et al. Trends in intense precipitation in the climate record. Journal of Climate 18, 1326-1350 (2005).

2. Min, S.-K., Zhang, X., Zwiers, F. W. \& Hegerl, G. C. Human contribution to moreintense precipitation extremes. Nature 470, 378-381 (2011).

3. Milly, P. C. D., Dunne, K. A. \& Vecchia, A. V. Global pattern of trends in streamflow and water availability in a changing climate. Nature 438, 347-350 (2005).

4. Pall, P. et al. Anthropogenic greenhouse gas contribution to flood risk in England and Wales in autumn 2000. Nature 470, 382-385 (2011).

5. Stahl, K. et al. Streamflow trends in Europe: evidence from a dataset of nearnatural catchments. Hydrology and Earth System Sciences 14, 2367-2382 (2010).

6. O'Connell, E., Ewen, J., O'Donnell, G. \& Quinn, P. Is there a link between agricultural land-use management and flooding? Hydrology and Earth System Sciences 11, 96-107 (2007).

7. Wheater, H. \& Evans, E. Land use, water management and future flood risk. Land Use Policy 26, S251-S264 (2009).

8. Wood, S., Sebastian, K. \& Scherr, S. J. Pilot analysis of global ecosystems: agroecosystems. Joint study by International Food Policy Research Institute and World Resources Institute, Washington D.C. (2000). < http://www.wri.org/ publication/pilot-analysis-global-ecosystems-agroecosystems $>$. Accessed Jan $31^{\text {st }} 2013$.

9. Macleod, C. J. A. et al. Genetically modified hydrographs: what can grass genetics do for temperate catchment hydrology? Hydrological Processes 21, 2217-2221 (2007).

10. Humphreys, M. W. et al. Discriminating the ancestral progenitors of hexaploid Festuca-arundinacea using genomic in-situ hybridization. Heredity 75, 171-174 (1995).

11. Ghesquiere, M., Humphreys, M. \& Zwierzykowski, Z. in Sustainable Use of Genetic Diversity in Forage and Turf Breeding (ed C. Huyghe) 495-509 (Springer, 2010).

12. Thomas, H. M., Morgan, W. G. \& Humphreys, M. W. Designing grasses with a future - combining the attributes of Loilium and Festuca. Euphytica 133, 19-26 (2003).

13. Daily, G. C. \& Matson, P. A. Ecosystem services: From theory to implementation. Proceedings of the National Academy of Sciences of the United States of America 105 (2008).

14. CEH. National Hydrological Monitoring Programme - Monthly Hydrological Summary for the UK (2009). <http://www.ceh.ac.uk/data/nrfa/nhmp/ monthly_hs.html $>$. Accessed Jan $31^{\text {st }} 2013$.

15. D’Odorico, P. et al. Ecohydrology of Terrestrial Ecosystems. Bioscience 60, 898-907 (2010)

16. do Rosario, G. et al. in Root Methods: A Handbook (eds A.L. Smit et al. ) 235-271 (Springer-Verlag, 2000). 
17. Allen, R. G., Pereira, L. S., Raes, D. \& Smith, M. Crop evapotranspirationGuidelines for computing crop water requirements- FAO Irrigation and drainage paper 56. (FAO - Food and Agriculture Organization of the United Nations, Rome 1998). <http://www.fao.org/docrep/X0490E/X0490E00.htm>. Accessed Jan $31^{\text {st }} 2013$

18. Michot, D. et al. Spatial and temporal monitoring of soil water content with an irrigated corn crop cover using surface electrical resistivity tomography. Water Resources Research 39 (2003).

19. Brunet, P., Clément, R. \& Bouvier, C. Monitoring soil water content and deficit using Electrical Resistivity Tomography (ERT) - A case study in the Cevennes area, France. Journal of Hydrology 380, 146-153 (2010).

20. Gregory, A. S. et al. Soil management and grass species effects on the hydraulic properties of shrinking soils. Soil Science Society of America Journal 74, 753-761 (2010)

21. Doerr, S. H., Ritsema, C. J., Dekker, L. W., Scott, D. F. \& Carter, D. Water repellence of soils: new insights and emerging research needs. Hydrological Processes 21, 2223-2228 (2007).

22. Matthews, G. P., Watts, C. W., Powlson, D. S., Price, J. C. \& Whalley, W. R. Wetting of agricultural soil measured by a simplified capillary rise technique. European Journal of Soil Science 59, 817-823 (2008).

23. Schäffer, B., Stauber, M., Mueller, T. L., Müller, R. \& Schulin, R. Soil and macropores under uniaxial compression. I. Mechanical stability of repacked soil and deformation of different types of macro-pores. Geoderma 146, 183-191 (2008).

24. Boorman, D. B., Hollis, J. M. \& Lilly, A. Hydrology of soil types: a hydrologicallybased classification of the soils of the United Kingdom. Institute of Hydrology, Natural Environment Research Council (1995).

25. Turner, L. et al. in Sustainable Use of Genetic Diversity in Forage and Turf Breeding (ed C. Huyghe) 471-478 (Springer, 2010).

26. Guo, D. L., Mitchell, R. J., Withington, J. M., Fan, P. P. \& Hendricks, J. J. Endogenous and exogenous controls of root life span, mortality and nitrogen flux in a longleaf pine forest: root branch order predominates. Journal of Ecology 96, 737-745 (2008).

27. Armstrong, A. C. \& Garwood, E. A. Hydrological Consequences of ArtificialDrainage of Grassland. Hydrological Processes 5, 157-174 (1991).

28. Krueger, T. et al. Ensemble evaluation of hydrological model hypotheses. Water Resources Research 46 (2010).

29. Scholefield, D. \& Stone, A. C. Nutrient losses in runoff water following application of different fertilisers to grassland cut for silage. Agriculture, Ecosystems and Environment 55, 181-191 (1995).
30. UMS. User Manual T4/T4e Pressure Transducer Tensiometer. (2011). < http:// www.ums-muc.de/fileadmin/produkt_downloads/Tensiometer/ T4_Manual.pdf $>$. Accessed Jan $31^{\text {st }} 2013$.

31. Binley, A. \& Kemna, A. in Hydrogeophysics (eds Y. Rubin \& S.S. Hubbard) 129-156 (Springer, 2005)

32. ProfileR version 2.5: 2-D Inversion of Surface Resistivity Data v. 2.5 (updated April 2008) Lancaster University, UK, Lancaster (2003). < http:// www.es.lancs.ac.uk/people/amb/Freeware/freeware.htm > . Accessed Jan $31^{\text {st }}$ 2013.

33. Hayley, K., Bentley, L. R., Gharibi, M. \& Nightingale, M. Low temperature dependence of electrical resistivity: Implications for near surface geophysical monitoring. Geophysical Research Letters 34 (2007).

\section{Acknowledgments}

This research was funded by a grant (BB/D010683/1) from the UK Biotechnology and Biological Sciences Research Council (BBSRC). Rothamsted Research and Institute of Biological, Environmental and Rural Sciences (IBERS) are grant funded by BBSRC. We thank A. Stone for helping construct and maintain the North Wyke field plots. We would also like to thank Roger White for assisting with the statistical analysis of the data.

\section{Author contributions}

C.J.A.M., M.W.H. and P.M.H.conceived the project. C.J.A.M. and A.J. set up the North Wyke plots and collected the data. C.J.A.M., M.W.H. and L.T. carried out the data processing. W.R.W., A.B. and C.W.W. helped carry out the soil physical and geophysical observations and analysis. M.W.H. led the plant aspects of the project. M.W.H., L.T., S.H S.O. and L.S. provided plant cultivars and carried out the IBERS pipe experiment. M.W.H., P.M.H. and W.R.W. helped C.J.A.M. write the paper.

\section{Additional information}

Competing financial interests: The authors declare no competing financial interests. License: This work is licensed under a Creative Common Attribution-NonCommercial-NoDerivs 3.0 Unported License. To view a copy of this license, visit http://creativecommons.org/licenses/by-nc-nd/3.0/

How to cite this article: J. A. Macleod, C (Kit). et al. A novel grass hybrid to reduce flood generation in temperate regions. Sci. Rep. 3, 1683; DOI:10.1038/srep01683 (2013). 